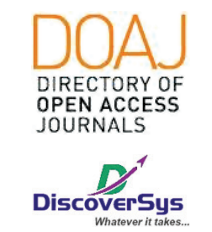

Published by DiscoverSys

\title{
Ekspresi tenascin-C yang tinggi pada ligamentum sakrouterina sebagai faktor risiko terjadinya prolaps uterus derajat III- IV di RSUP Sanglah Denpasar, Bali-Indonesia
}

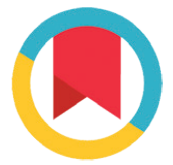

CrossMark

\author{
I Wayan Megadhana, ${ }^{1}$ Riza Firman Satria, ${ }^{2 *}$ Ketut Suwiyoga, ${ }^{1}$ \\ I Gusti Putu Mayun Mayura, ${ }^{1}$ Putu Doster Mahayasa, ${ }^{1}$ I Nyoman Bayu Mahendra ${ }^{1}$
}

\section{ABSTRACT}

Introduction: Uterine prolapse is the descent of the uterus into the vagina or out of the vagina as a result of the failure of the ligament as a pelvic support. Uterine prolapse has multifactorial risk factors, but in every case of uterine prolapse, weakness is found in the pelvic floor supporting tissues, including the sacrouterine ligament. Childbirth is direct trauma that cause damage and weakness of levaor ani muscle, which leads to stretch of sacrouterine ligament that plays important role in maintaining uterus in its normal position. The main structure of the sacrouterine ligament consists of cells and extracellular matrix such as collagen, elastin, glycoproteins (fibronectin, tenascin, link protein, fibromodulin and dan osteopontin) and proteoglycans (agrecan, versican, biglican, dan perlecan). Tenascin is a major oligomeric glycoprotein found in the extracellular matrix. Tenascin has an important role not only during development but also when there are pathological conditions in adulthood such as tissue injury and tumorigenesis. Based on the current research, there are four tenascin groups, that are: tenascin- $C$, tenascin- $R$, tenascin- $X$, tenascin- $Y$ and tenascin- $W$. If there is an expression of
tenascin-C disturbance in the sacrouterine ligament, it will cause uterine prolapse. The purpose of this study was to prove the high expression of tenascin- $\mathrm{C}$ in the sacrouterine ligament as a risk factor for stage III-IV uterine prolapse.

Method: This research is an observational study with case control design. Forty four cases was included in this study. Twenty-two cases of III-IV degree uterine prolapse as study group and another 22 nonprolapse cases as a control group. This research was carried out in Sanglah General Hospital and Patobiology Laboratory of the Faculty of Veterinary Medicine UNUD. Samples were taken from the sacrouterine ligament of grade III-IV uterine prolapse patients and uterine nonprolapse patients, that had been performed total hysterectomy.

Result: The results showed that high tenascin-C expression was a risk factor for stage III - IV uterine prolapse by 5.9 times $(O R=5.9$; IK $95 \%=1.59-22.32 ; p=0.006$ ).

Conclusion: It can be concluded that high expression of tenascin- $C$ in the sacrouterine ligament is a risk factor of III-IV degree uterine prolapse.

Keywords: Tenascin-C, Grade III-IV Uterine Prolapse.

Cite This Article: Megadhana, I.W., Satria, R.F., Suwiyoga, K., Mayura, I.G.P.M., Mahayasa, P.D., Mahendra, I.N.B. 2020. Ekspresi tenascin-C yang tinggi pada ligamentum sakrouterina sebagai faktor risiko terjadinya prolaps uterus derajat III-IV di RSUP Sanglah Denpasar, Bali-Indonesia. Intisari Sains Medis 11(2): 845-850. D0I: 10.15562/ism.v11i2.791

'Departemen/KSM Obstetri dan Ginekologi, Fakultas Kedokteran, Universitas Udayana-RSUP Sanglah Denpasar, Bali-Indonesia 2PPDS-1 Obstetri dan Ginekologi, Fakultas Kedokteran, Universitas Udayana-RSUP Sanglah Denpasar, Bali-Indonesia

\section{${ }^{*}$ Correspondence to:}

Riza Firman Satria, PPDS-1 Obstetri dan Ginekologi, Fakultas Kedokteran, Universitas Udayana-RSUP Sanglah Denpasar, Bali-Indonesia drizafirman@gmail.com

Diterima: $10-07-2020$

Disetujui: 28-07-2020

Diterbitkan: 01-08-2020

\section{ABSTRAK}

Latar Belakang: Prolaps uterus adalah turunnya uterus ke dalam liang vagina atau keluar liang vagina sebagai akibat gagalnya ligmentum penyokong dasar panggul. Prolaps uterus memiliki faktor risiko yang bersifat multifaktorial, namun pada setiap kasus prolaps uterus, selalu ditemukan kelemahan pada jaringan penyangga dasar panggul, termasuk ligamentum sakrouterina. Trauma langsung pada jalan lahir yang mengakibatkan kerusakan dan kelemahan otot levaor ani sehingga mengakibatkan ligamentum sakrouterina meregang untuk mempertahankan uterus dalam posisi normal. Struktur utama ligamen sakrouterina terdiri dari sel dan matriks ekstraseluler seperti kolagen, elastin, glikoprotein (fibronectin, tenascin, link protein, fibromodulin) dan proteoglikan (agrecan, versican, biglican, dan perlecan). Tenascin merupakan suatu glikoprotein oligomerik utama yang terdapat pada matriks ekstraseluler. Tenascin memiliki peranan penting tidak hanya pada masa perkembangan tetapi juga saat terjadi kondisi patologis pada usia dewasa seperti cedera jaringan dan tumorigenesis. Berdasarkan penelitian saat ini, dikenal empat kelompok tenascin yaitu: tenascin- $C$, tenascin- $R$, tenascin- $X$, tenascin- $Y$ dan tenascin- $W$. Apabila terjadi gangguan dalam ekspresi tenascin-C pada ligamentum sakrouterina akan menyebabkan terjadinya prolaps uterus. Tujuan penelitian ini adalah untuk membuktikan ekspresi tenascin-C yang tinggi pada ligamentum sakrouterina sebagai faktor risiko terjadinya prolaps uterus derajat III-IV.

Metode: Penelitian ini merupakan rancangan observasional dengan kasus kontrol. Terdapat 22 kasus prolaps uterus derajat III-IV sebagai kelompok kasus dan 22 kasus non prolaps sebagai kelompok kontrol. Penelitian ini dikerjakan di RSUP Sanglah dan Laboratorium Patobiologi FKH UNUD. Sampel diambil dari ligamentum sakrouterina pasien prolaps uterus derajat III-IV dan non-prolaps uterus yang telah dilakukan histerektomi total. 
Hasil: Hasil penelitian didapatkan bahwa ekspresi tenacin-C yang tinggi merupakan faktor risiko terjadinya prolaps uterus derajat III - IV sebesar 5,9 kali (OR =5,9; IK 95\% =1,59-22,32; $\mathrm{p}=0,006)$.
Simpulan: Sehingga dapat disimpulkan bahwa ekspresi tenascin-C yang tinggi pada ligamentum sakrouterina sebagai faktor risiko terjadinya prolaps uterus derajat III-IV.

Kata kunci: Tenascin-C, Prolaps uterus derajat III-IV.

Cite Pasal Ini: Megadhana, I.W., Satria, R.F., Suwiyoga, K., Mayura, I.G.P.M., Mahayasa, P.D., Mahendra, I.N.B. 2020. Ekspresi tenascin-C yang tinggi pada ligamentum sakrouterina sebagai faktor risiko terjadinya prolaps uterus derajat III-IV di RSUP Sanglah Denpasar, Bali-Indonesia. Intisari Sains Medis 11(2): 845-850. D0I: 10.15562/ism.v11i2.791

\section{PENDAHULUAN}

Prolaps uterus saat ini masih merupakan masalah kesehatan di dunia, terkait prevalensi, hal ini mempengaruhi kualitas hidup wanita dewasa. Prolaps uterus dapat disamakan dengan suatu hernia, yaitu uterus turun ke dalam vagina, bahkan mungkin ke luar liang vagina yang disebabkan oleh melemahnya otot - otot dasar panggul, ligamentum dan fasia yang menyokong uterus. Prolaps uterus merupakan salah satu bagian dari kelainan prolaps organ panggul (POP). Prolaps uterus umumnya tidak mengancam nyawa tetapi mengganggu kehidupan psikososial, ekonomi dan fungsi seksual penderitanya. Menurunnya pencitraan diri akibat gangguan fisik merupakan dampak prolaps uterus dari aspek psikososial. Tingginya biaya pengobatan untuk mengatasi gangguan fisik serta biaya operasi perbaikan prolaps adalah beban ekonomi yang harus ditanggung oleh penderita prolaps uterus.

Angka kejadian prolaps organ panggul meningkat sesuai dengan meningkatnya usia dan jumlah persalinan. ${ }^{1}$ POP merupakan kondisi yang umum terjadi pada wanita, tetapi angka prevalensi yang sebenarnya sulit untuk ditentukan, karena keluhan pada wanita dengan POP biasanya akan dirasakan bila prolaps turun sampai himen atau bahkan sampai diluar vagina. ${ }^{2}$ Berdasarkan studi epidemologi terbaru, angka kejadian POP di seluruh dunia dilaporkan sekitar $9 \% .^{3}$ Namun angka prevalensi ini berbeda pada negara dengan tingkat ekonomi rendah yaitu diperkirakan sekitar 20\%. ${ }^{4}$ Penelitian Horst dkk. (2016) di Brazil dengan menggunakan Pelvic Organ Prolapse Quantification system (POP-Q) melaporkan prevalensi prolaps organ panggul bervariasi berdasarkan derajatnya yaitu POP derajat I $27,8 \%$, POP derajat II $23,1 \%$ dan POP derajat III 1,3\%.

Dasar panggul merupakan suatu komplek jaringan yang terletak diantara peritoneum viseralis bagian bawah sampai dengan kulit vulva, yang memiliki peranan untuk menyokong berbagai organ viseralis pada panggul agar tetap berada dalam posisi dan fungsinya yang normal. Patel dkk. menggolongkan faktor risiko prolaps uterus menjadi faktor intrinsik yaitu genetik, umur, status postmenopouse, ras, dan faktor ekstrinsik seperti, persalinan, riwayat histerektomi, dan jenis pekerjaan. ${ }^{5}$ Pengaruh kehamilan, persalinan, maupun peningkatan tekanan intra-abdominal seperti: batuk kronis dan beban pekerjaan berat dapat menyebabkan kerusakan atau melemahnya kekuatan otot levator ani. Otot levator ani merupakan penyangga utama dasar panggul. Jika otot levator ani normal, maka hiatus genitalis menutup, uterus tetap pada posisi normal dengan ligamentum sakrouterina dalam keadaan relaksasi. Akan tetapi, jika otot ini melemah atau mengalami trauma pada saat persalinan mengakibatkan hiatus genitalis membuka dan mungkin dapat terjadi prolaps stadium ringan (stadium I dan II). Untuk mencegah prolaps uterus lebih berat, maka ligamentum sakrouterina berkontraksi mempertahankan uterus tetap pada posisi normal. Jika ligamentum sakrouterina mengalami kerusakan atau melemah, maka tidak mampu lagi mempertahankan uterus pada posisi normal, sehingga terjadi prolaps uterus stadium lebih berat yaitu stadium III-IV. Jadi ligamentum sakrouterina memegang peranan penting dalam patofisiologi terjadinya perburukan prolaps uterus. $^{6}$

Ligamentum sakrouterina mempunyai struktur utama yang terdiri dari sel dan matriks ekstraselular. Matriks ekstraselular tersusun dari fiber (kolagen dan elastin), glikoprotein (fibronectin, tenascin, link protein, fibromodulin, osteopontin) dan proteoglikan (aggrecan, versican, biglycan, decorin, perlecan). ${ }^{7,8}$ Matriks ekstraselular selain mempunyai fungsi struktural dalam jaringan, juga merupakan tempat terjadinya proses proliferasi, adhesi, migrasi, differensiasi, dan remodeling. ${ }^{10}$ Tenascin merupakan suatu glikoprotein oligomerik utama yang terdapat pada matriks ekstraselular. Tenascin memiliki peranan penting tidak hanya pada masa perkembangan tetapi juga saat terjadi kondisi patologis pada usia dewasa seperti cedera jaringan dan tumorigenesis. Berdasarkan penelitian saat ini, dikenal empat kelompok tenascin yaitu: tenascin- $C$, tenascin- $R$, tenascin- $X$, dan tenascin-W. Setiap tenascin mempunyai pola 
ekspresi yang spesifik. ${ }^{10}$ Tenascin-C berperan pada migrasi fibroblas dan penyembuhan luka. Ekpresi tenascin-C yang tinggi pada jaringan luka akan meningkatkan infiltrasi fibroblas kedalam matriks sementara yang berfungsi menggantikan matriks yang rusak. Ketika sel menghasilkan matriks yang sesuai, myofibroblas akan menghilang karena apoptosis ataupun kembali berdiferensiasi menjadi fibroblas. Akan tetapi jika terjadi regangan mekanik, myofibroblas mungkin tidak akan hilang, hal ini akan membuat matriks menjadi kaku dan terbentuk jaringan fibrotik. ${ }^{12,29}$

Percobaan yang dilakukan pada tikus didapatkan defisiensi tenacin-C menimbulkan hambatan infiltrasi myofibroblas pada infark myokard. Hal ini menunjukkan bahwa tenascin-C dapat meningkatkan reepitelisasi pada tahap akhir perbaikan jaringan cedera. ${ }^{13}$ Penelitian lainnya yang dilakukan pada tikus dengan defisiensi tenascin- $\mathrm{C}$ menunjukkan penurunan migrasi keratinosit pada epidermis jaringan luka. Hal ini menunjukkan peranan tenascin- $\mathrm{C}$ sangat penting pada re-epitelisasi dan granulasi jaringan baru. ${ }^{13}$ Penelitian Ewies dkk. melaporkan ekspresi tenascin yang tinggi pada ligamentum kardinale wanita dengan prolaps uteri tanpa memandang status menopouse dan pada wanita yang tidak prolaps, ekspresi tenascin secara signifikan lebih tinggi didapatkan pada usia menopouse. ${ }^{7}$ Sedangkan pada dinding arteri wanita tanpa prolaps didapatkan gambaran imunohistokimia tenascin yang secara spesifik lebih rendah dibandingkan dengan wanita dengan prolaps derajat IV. Hal ini menjadikan suatu pemikiran bahwa peningkatan ekspresi tenascin merupakan suatu respon dari peregangan mekanik. ${ }^{14}$

Meskipun banyak faktor risiko yang diketahui mempengaruhi terjadinya prolaps uterus namun patogenesis bagaimana hal tersebut timbul masih banyak yang belum diketahui. Oleh karena itu tujuan dari penelitian ini adalah untuk melakukan evaluasi ekspresi tenasin-C yang tinggi pada ligamentum sakrouterina sebagai faktor risiko terjadinya prolaps uterus derajat III-IV.

\section{METODE}

\section{Rancangan penelitian dan populasi}

Jenis penelitian ini adalah observasional dengan kasus kontrol. Kasus adalah penderita prolaps uterus derajat III-IV yang telah dilakukan histerektomi total. Kontrol adalah penderita non prolaps uterus yang telah dilakukan histerektomi total atas indikasi kelainan jinak seperti mioma uteri atau gangguan perdarahan. Secara sistematik rancangan penelitian dapat digambarkan sebagai berikut. Penelitian ini dilakukan di RSUP Sanglah Denpasar, selama periode 6 bulan mulai dari 18 Oktober 2019. Kriteria inklusi dalam penelitian ini adalah prolapse uteri derajat III-IV yang telah dilakukan histerektomi total, usia 35-70 tahun, dan bersedia ikut dalam penelitian setelah menerima informed consent. Kriteria eksklusi dalam penelitian ini adalah riwayat terapi hormon dan keganasan uterus (malignant uterine cancer).

\section{Pemeriksaan tenascin-C}

Gambaran tenascin-C dari tiap blok parafin yang dipotong dan sedian diwarnai dengan antibodi tenascin-C untuk pemeriksaan imunohistokimia. Preparat kemudian diperiksa di mikroskop cahaya untuk menilai ekspresi tenascin-C yang memberikan warna coklat. Ekspresi tenascin-C merupakan intensitas daerah berwarna coklat pada jaringan ligamentum sakrouterina yang diwarnai dengan pemeriksaan imunohistokimia yang dilakukan di Laboratorium Fakultas Kedokteran Hewan Universitas Udayana. Intensitas berwarna coklat kemudian di kuantifikasi dengan metode analisis digital. Pengamatan hasil jumlah ekspresi tenascin- $\mathrm{C}$ dilakukan dengan metode analisis digital. Sediaan dengan pembesaran 400 kali. Perhitungan kualitatif kemudian akan dirubah menjadi perhitungan kuantitatif dengan menggunakan program ImageJ. Dengan menggunakan fungsi "Inverse" maka terpilihlah pixel selain warna coklat, lalu dihapus menggunakan fungsi "delete" sehingga pada gambar hanya tersisa pixel dengan warna coklat. Ekspresi tenascin- $\mathrm{C}$ dihitung sebagai presentase pixel area kolagen yang berwarna coklat dibandingkan dengan pixel area seluruh jaringan. Pertama, gambar yang sudah dihilangkan pixel selain warna coklat, dipisah channel warnanya melalui fungsi "RGB stack" pada Image J. Kemudian dibuat nilai "threshold", lalu dijalankan fungsi "measure" sehingga didapatkan presentase pixel warna coklat dari total pixel secara otomatis.

\section{Analisis statistik}

Analsisi data dalam penelitian ini menggunakan program SPSS versi 21.0. Analisis deskriptif digunakan untuk melihat distribusi dari karakteristik sampel dalam penelitian. Analisis receiver operating curve (ROC) digunakan untuk menggambarkan nilai titik potong dari hasil pemeriksaan tenascin-C terhadap kejadian prolapss uteri, kemdudian dilanjutkan dengan uji chi-square dan perhitungan rasio odds untuk mengkaji peranan ekspresi tenascin-C yang tinggi sebagai faktor risiko dari prolapse uteri. Seluruh nilai dianggap bermakna apabila $\mathrm{p}<0,05$

\section{HASIL PENELITIAN}

Studi kasus kontrol pada 22 kasus prolaps uterus derajat III-IV sebagai kelompok kasus dan 22 kasus 
non prolaps sebagai kelompok kontrol yang dilaksanakan di Bagian/SMF Obstetri dan Ginekologi RSUP Sanglah Denpasar selama 6 bulan, yaitu dimulai sejak tanggal 18 Oktober 2019. Karakteristik sampel penelitian pada tabel 1 menunjukkan variabel umur, paritas, IMT dan pekerjaan didapatkan nilai $\mathrm{p}$ untuk masing-masing faktor risiko adalah $>0,05$, yang menyatakan bahwa tidak adanya perbedaan bermakna antara kedua kelompok.

Tabel 2, menunjukkan bahwa ekspresi tenascin-C yang tinggi merupakan faktor risiko terjadinya prolaps uterus derajat III - IV sebesar 5,9 kali $(\mathrm{OR}=5,9$; IK 95\% =1,58-22,32; $\mathrm{p}=0,006)$ dibandingkan ekspresi tenascin-C yang rendah, dengan nilai cut of point sebesar 1,772 berdasarkan kurva ROC. Gambaran ekspresi tenascin-C pada

Tabel 1 Karakteristik sampel penelitian

\begin{tabular}{lccc}
\hline & \multicolumn{2}{c}{ Kelompok } & \\
\cline { 2 - 3 } Variabel & $\begin{array}{c}\text { Kasus } \\
(\mathbf{n = 2 2})\end{array}$ & $\begin{array}{c}\text { Kontrol } \\
(\mathbf{n = 2 2})\end{array}$ & $\mathbf{p}$ \\
\hline Umur (tahun), rerata \pm SD & $51,32 \pm 4,46$ & $49,23 \pm 2,96$ & $0,08^{\mathrm{a}}$ \\
Paritas (anak), median (IQR) & $3,14(1,08)$ & $2,77(0,92)$ & $0,24^{\mathrm{b}}$ \\
IMT (kg/m2), rerata \pm SD & $21,89 \pm 1,93$ & $23,00 \pm 2,14$ & $0,08^{\mathrm{a}}$ \\
Pekerjaan & & & \\
- Ringan, n (\%) & $14(63,6)$ & $10(45,5)$ & $0,226^{\mathrm{c}}$ \\
\hline
\end{tabular}

Keterangan: $\mathrm{a}=$ Independent $\mathrm{T}$-test, $\mathrm{b}=$ Mann-Whitney test, $\mathrm{c}=$ Chi-square test

Tabel 2 Risiko prolaps uterus derajat III-IV pada ekspresi tenascin-c

\begin{tabular}{|c|c|c|c|c|c|c|}
\hline \multirow[b]{2}{*}{ Variabel } & & \multicolumn{2}{|c|}{ Kelompok } & \multirow[b]{2}{*}{ OR } & \multirow[b]{2}{*}{ IK 95\% } & \multirow[b]{2}{*}{$\mathbf{p}$} \\
\hline & & $\begin{array}{c}\text { Kasus } \\
(n=22)\end{array}$ & $\begin{array}{c}\text { Kontrol } \\
(n=22)\end{array}$ & & & \\
\hline \multirow[t]{2}{*}{ Ekspresi Tenascin-C } & Tinggi & 14 & 5 & 5,9 & $1,58-2,32$ & 0,006 \\
\hline & Rendah & 8 & 17 & & & \\
\hline
\end{tabular}
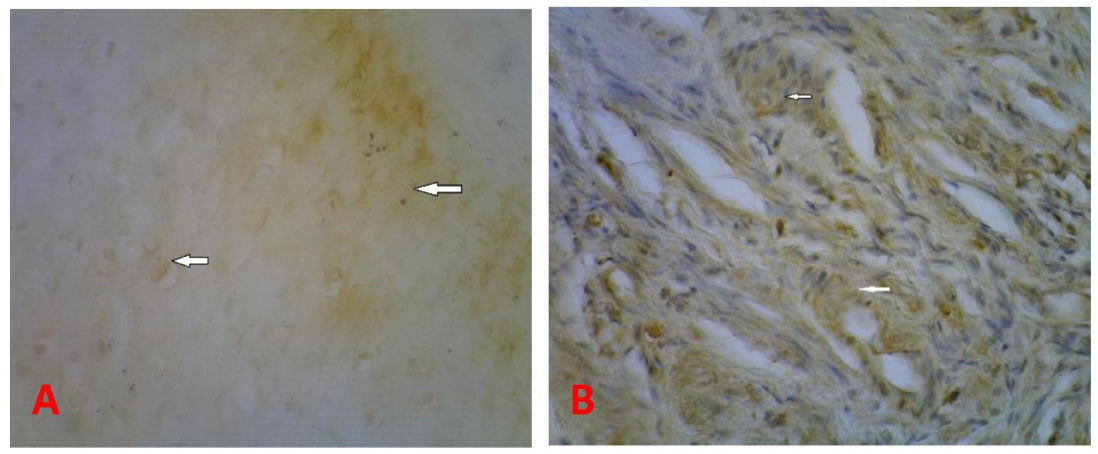

Gambar 1 Ekspresi Tenascin-C pada Jaringan Ligamentum Sakrouterina dengan Pengecatan Imunohistokimia; A: Kelompok kontrol. Tampak tanda panah putih menunjukkan ekspresi tenascin-C (warna coklat) yang rendah; B: Kelompok kasus. Tampak tanda panah putih menunjukkan ekspresi tenascin-C (warna coklat) yang tinggi kelompok kasus dan kelompok kontrol dapat dilihat pada gambar 1 .

\section{PEMBAHASAN}

Pada penelitian ini didapatkan perbedaan bermakna dalam tingkat ekspresi tenascin-C pada ligamentum sakrouterina antara kelompok kasus dan kontrol $(p=0,006)$, dimana didapatkan bahwa mayoritas subjek pada kelompok kasus memiliki tingkat ekspresi tenascin-C yang tinggi $(n=14)$ dibandingkan dengan kelompok kontrol $(n=9)$. Sebaliknya, pada kelompok kontrol, mayoritas $(n=17)$ memiliki ekspresi tenascin-C yang rendah dibandingkan dengan kelompok kasus $(\mathrm{n}=8)$.

Ligamentum sakrouterina merupakan kondensasi dari fasia endopelvik yang menjadi penyokong utama yang mempertahankan uterus agar tetap pada tempatnya. ${ }^{15}$ Ligamen merupakan lapisan jaringan ikat yang sebagian besar terdiri dari jaringan kolagen dengan daya tensile strength yang tinggi. Sel- sel pada ligamen sebagian besar terdiri dari fibroblas. ${ }^{16}$ Kolagen menyusun $70-80 \%$ dari serat - serat ligamen yang sebagian besar adalah kolagen tipe I dan sebagian kecil kolagen tipe III, V dan VI. ${ }^{17}$ Ligamentum sakrouterina tersusun atas sel (fibroblas atau jaringan ikat fibrous) dan matriks ekstraseluler yang terdiri dari fiber (kolagen dan elastin), glikoprotein (Fibronektin, Tenascin, Link protein, Fibromodulin, Osteopontin) dan proteoglikan (Aggrekan, Versikan, Biglykan, Dekorin, Perlekan)..$^{18}$

Tenascin merupakan glikoprotein oligomerik dari matrik ekstraseluler. Tenascin diklasifikasikan menjadi empat jenis yaitu tenascin- $C$, tenascin- $R$, tenascin- $\mathrm{X}$, dan tenascin- $\mathrm{W}$ yang mengalami oligomerisasi menjadi struktur trimerik (tenascin-R) atau heksamerik (tenascin-C, $-\mathrm{X}$, dan -W). Tenascin berfungsi sebagai modulator dari adhesi sel, migrasi, dan pertumbuhan. Modul tipe III dalam tenascin, serta fibronektin, berikatan dengan $V E G F$ dan merangsang proliferasi sel dengan cara berikatan dengan integrin. ${ }^{19}$ Tenascin jarang terdistribusi normal pada ligamen, tetapi ekspresinya akan meningkat secara nyata pada ligamentum yang ruptur, hal ini mengindikasikan keterlibatan tenascin pada proses remodeling setelah terjadi cedera pada ligamen. ${ }^{20}$ Tenascin dikespresikan dengan pola yang dinamis dan sangat terbatas pada embrio saat perkembangan syaraf, skeletogenesis dan vasculogenesis. Ekspresinya akan meningkat saat terjadi regenerasi sel syaraf, penyembuhan luka dan involusi jaringan. Regulasi tenascin juga akan meningkat pada proses tumorigenesis, metastasis dan pada penyakit - penyakit pembuluh darah. ${ }^{19}$ Tenascin berperan pada gerakan morfogenetik, pola dan remodeling jaringan. ${ }^{21}$ Tenascin pada 
umumnya ditemukan dalam jaringan dewasa yang mengalami remodeling aktif, seperti penyembuhan luka dan tumor. ${ }^{22}$

Tenascin-C adalah golongan tenascin yang pertama kali ditemukan. Tenascin-C merupakan protein yang diduga berperan dalam proses adhesi sel terhadap kolagen fibroblast. ${ }^{19}$ Ekspresi tenascin-C meningkat selama embriogenesis, remodeling tulang pada jaringan dewasa, dan inflamasi. Peningkatan kadar tenascin-C juga berkorelasi dengan derajat tumor, dan merupakan penanda diagnostik remodeling jaringan ikat dalam kondisi patologis. ${ }^{23}$ Ekpresi tenascin-C yang tinggi pada jaringan luka akan meningkatkan infiltrasi fibroblas kedalam matriks sementara yang berfungsi menggantikan matriks yang rusak. ${ }^{16}$ Ketika sel menghasilkan matriks yang sesuai, myofibroblas akan menghilang karena apoptosis ataupun kembali berdiferensiasi menjadi fibroblas. Akan tetapi jika terjadi regangan mekanik, myofibroblas mungkin tidak akan hilang, hal ini akan membuat matriks menjadi kaku dan terbentuk jaringan fibrotik. ${ }^{24}$ Percepatan remodeling ligamentum pada wanita POP berperan pada perubahan bikomia matriks ekstraselular. Penelitian yang dilakukan Zong dkk. ${ }^{25}$ pada pelat yang dilapisi dengan kolagen tipe I melaporkan fibroblas pada wanita dengan POP tidak dapat memberikan respon sel yang sama dengan kontrol, dimana fibroblas pada wanita POP diduga tidak dapat mengembalikan homeostasis matrik ekstraselular. Dalam kondisi ini, renovasi jaringan tidak dapat pulih dan akan memperburuk matriks ekstraselular, yaitu hilangnya kekuatan dan meningkatkan kekakuan yang pada akhirnya akan terjadi kerusakan jaringan yang lebih banyak..$^{25}$

Pada penelitian ini, ekspresi tenascin-C yang tinggi merupakan faktor risiko terjadinya prolaps uterus derajat III - IV sebesar 5,9 kali ( OR =5,9; IK $95 \%=1,58-22,32 ; p=0,006)$ dibandingkan ekspresi tenascin-C yang rendah. Hal ini serupa dengan penelitian Goepel dkk. ${ }^{14}$ mengenai perbedaan ekspresi elastin dan tenascin pada ligamentum sakrouterina dengan menggunakan immunofluorescence microscopy. Penelitian ini melaporkan adanya peningkatan ekspresi tenascin secara signifikan pada wanita dengan prolaps organ panggul $(\mathrm{p}<0,001)$. Serupa dengan penelitian yang dilakukan oleh Muliakusumah dkk. ${ }^{26}$ juga menunjukkan kadar tenascin yang tinggi pada ligamentum sakrouterina pasien prolaps uteri dibandingkan dengan pasien non prolaps dengan nilai $\mathrm{p}=0,001$. Demikian juga penelitian yang dilakukan oleh Aznal dkk. ${ }^{27}$ yang menggunakan metode imunohistokimia melaporkan ekspresi tenascin yang lebih tinggi pada ligamen sakrouterina dari kelompok wanita post menopause dengan POP dibandingkan wanita post menopause tanpa POP dan wanita premenopouse dengan nilai $\mathrm{p}<0,01$. Hal ini serupa dengan penelitian yang dilakukan oleh Lusiadewi dkk. ${ }^{28}$ melaporkan peningkatan tenascin yang tinggi pada ligamentum sakrouterina pada wanita dengan POP dibandingkan dengan pasien non prolaps, dimana ekspresi tenascin pada kasus terbanyak adalah intensitas tenascin kuat (51,4\%). Ekspresi tenascin pada kontrol terbanyak adalah intensitas tenascin lemah $(77,1 \%)$ dengan nilai $\mathrm{p}=0,000$. Penelitian Ewies dkk. ${ }^{7}$ melaporkan ekspresi tenascin yang tinggi ligamentum kardinale pada wanita dengan prolaps uteri tanpa memandang status menopouse dengan nilai $\mathrm{p}<0,001$ dan pada wanita yang tidak prolaps ekspresi tenascin secara signifikan lebih tinggi didapatkan pada usia menopause dengan nilai $\mathrm{p}=0,03$.

\section{SIMPULAN}

Berdasarkan hasil penelitian didapatkan simpulan sebagai berikut: ekspresi tenascin-C yang tinggi pada ligamentum sakrouterina merupakan faktor risiko terjadinya prolaps uterus derajat III-IV.

\section{KONFLIK KEPENTINGAN}

Penulis menyatakan tidak terdapat konflik kepentingan terkait publikasi dari artikel ini.

\section{PENDANAAN}

Penelitian ini tidak mendapat pendanaa dari pemerintah ataupun lembaga sektor swasta lainnya.

\section{ETIKA DALAM PENELITIAN}

Penelitian ini telah disetujui oleh Komite Etik, Fakultas Kedokteran, Universitas Udayana/RSUP Sanglah Denpasar.

\section{DAFTAR PUSTAKA}

1. Rortveit G, Brown JS, Thom DH, Van Den Eeden SK, Creasman JM, Subak LL. Symptomatic Pelvic Organ Prolapse: Prevalence and Risk Factors in A PopulationBased, Racially Diverse Cohort. Obstet Gyneco. 2007;109:1396-403.

2. Swift SE, Woodman P, O'Boyle AL. Pelvic Organ Support Studdy (POSST): The Distribution, Clinical Definition, and Epidemiologic Condition of Pelvic Organ Support Defects. Am J Obstet Gynecol. 2005;192(3):1-8.

3. Vos T. Years Lived with Disability (YLDs) for 1160 Sequelae of 289 Diseases and Injuries 1990-2010: A Systematic Analysis for The Global Burden of Disease Study 2010. Lancet. 2012;380(9859):2163-96.

4. Walker GJ, Gunasekera P. Pelvic Organ Prolapse and Incontinence in Developing Countries: Review of Prevalence and Risk Factors. Int Urogynecol J. 2011;22(2): 127-35.

5. Patel PD, Amrute KV, Badlani GH. Pelvic Organ Prolapse and Stress Urinary Incontinence: A Review of Etiological Factors. Indian Journal of Urology. 2007;12:135-41. 
6. Cole EE, Leu PB, Gomelsky A, Revelo P, Shappell H, Scarpero H, Scarpero HM, Dmochowski RR. Histophatological Evaluation of Uterosacral Ligament; Is This A Dependable Structure for Pelvic Reconstruction?. BJU International. 2005;97:345-8.

7. Ewies AAA, Al-Azzawi F, Thompson J. Changes in Extracellular Matrix Proteins in The Cardinal Ligament of Post-Menopousal Women With or Without Prolapse: A Computerized Immunohistomorphometric Analysis. 2003. Int J Obstet Gynecol. 12(2): 2109-2195.

8. Lin SY, Tee YT, Chenn S, Chang H, Lin P, Chen GD. Changes in The Extracellular Matrix in The Anterior Vagina of Women With or Without Prolapse. Int Urogynecol J Pelvic Dysfunct. 2006;18:43-8.

9. Leppert PC. Tissue Remodeling in The Female Reproductive Tract - A Complex Process Becomes More Complex: The Role of Hox Genes. Biology of Reproduction. 2012;86(4):98,1-3.

10. Hsia HC, Schwarzbauer JE. Meet The Tenascins: Multifungtional and Mysterious. The Journal of Biological Chemistr. 2005;280(29):26641-26644.

11. Tran KT, Lamb P, Deng JS. Matrikines and Matricryptins: Implications for Cutaneous Cancers and Skin Repair. J Dermatol Sci. 2005;40(1):11-20.

12. Blaauboer ME, Smit TH, Hanemaaijer R, Stoop R, Everts V. Cyclic Mechanical Stretch Reduces Myofibroblast Differentiation of Primary Lung Fibroblasts. Biochem Biophys Res Commun. 2011;404:23-27.

13. Midwood KS, Schwarzbauer JE. Tenascin-C Modulates Matrix Contraction Via Focal Adhesion Kinase and Rho Mediated Signaling Pathways. Molecular Biology of The Cell. 2002;13:3601-3613.

14. Goepel C, Kantelhardt EJ, Karbe I, Stoerer S, Dittmer J. Changes of Glycoprotein and Collagen Immunolocalization in The Uterine Artery Wall of Postmenopausal Women With and Without Pelvic Organ Prolapse. Acta Histochemica. 2011;113(2011):375-381.

15. Tinelli A, Malvasi A, Rahimi S, Negro R, Vergara D. Review Article: Age-related pelvic floor modifications and prolapse risk factors in postmenopausal women. Menopause: The Journal of The North American Menopause Society. 2010;17(1):204-12.

16. Hart D, Frank CB, Bray RC. Repetitive Motion Disorders of the Upper Extremities. American Academy of Orthopedics Surgeons, Rosemont. 1995; p. 247-262.

17. Benjamin M, Ralphs JR. Tendons and Ligaments - An Overview. Histol. Histopathol. 1997; p. 1135-1144.

18. Kerkhof MH, Hendriks L, Brolmann HAM. Changes in Connective Tissue in Patient with Pelvic Organ Prolapsed A Review of The Current Literature. Int Urogynecol J. 2009;20: 461-474.
19. Jones FS, Jones PL. The Tenascin Family of ECM Glycoproteins; Structure, Function, and Regulation During Embrionic Development and Tissue Remodeling. Developmental Dynamics. 2000;218:235-259.

20. Neurath M. Expression of Tenascin, Laminin, and Fibronectin Following Rupture of The Anterior Cruciate Ligament. Z Orthop. 1993;131:168-72.

21. Liu JM, Davidson JM. The Elastogenic Effect of Recombinant Transforming Growth Factor Beta on Porcine Aortic Smooth Muscle Cells. Biochem Biophys Res Commun. 1988;154: 895-901.

22. Wallner K, Li C, Shah PK, Fishbein MC, Forrester JS, Kaul S. Tenascin-C is Expressed in Macrophagerich Human Coronary Atherosclerotic Plaque. Circulation. 1999;99:1284-9.

23. Kaur J, Reinhardt DP. Extracellular Matrix Molecules. Stem Cell Biology and Tisuue Enginering in Dental Sciences. 2015;3(2):12-19.

24. Blaauboer ME, Smit TH, Hanemaaijer R, Stoop R, Everts V. Cyclic Mechanical Stretch Reduces Myofibroblast Differentiation of Primary Lung Fibroblasts. Biochem Biophys Res Commun. 2011;404:23-27.

25. Zong W, Jallah ZC, Stein SE, Abramowitch SD, Moalli PA. Repetitive Mechanical Stretch Increases Extracellular Collagenase Activity in Vaginal Fibroblasts. Female Pelvic Med Reconstr Surg. 2010;16:257-262.

26. Muliakusumah A, Purwara BH, Sasotya S. Correlation between Content of Collagen I and Tenascin-C Sacrouterine Ligament in the Uterine Prolapse. Indones J Obstet Gynecol. 2011;35(4):12-19.

27. Aznal SSS, Meng FG, Nalliah S, Tay A, Chinniah K, Jamli MF. Biochemical Evaluation of The Supporting Structure of Pelvic Organs in Selected Numbers of Premenopousal and Postmenopousal Malaysian Women. Indian Journal of Pathology and Microbiology. 2012;55(4):55-62.

28. Lusiadewi E, Irianta T, Lukas E. Expression of Tenascin in The Uterosacral Ligament is Stronger in Women with Pelvic Organ Prolapse. Indonesian Journal of Obstetrics and Gynecology. 2013;1(4):199-203.

29. Putra IGM, Manuaba IBAP, Pranamartha AAGMK, Bhargah A. The role of estrogen receptor a, COL3A1, and fibulin-5 genes polymorphisms as risk factors for pelvic organ prolapse in Balinese women. Gineco.eu. 2018;14(4):135-140. DOI: 10.18643/gieu.2018.135.

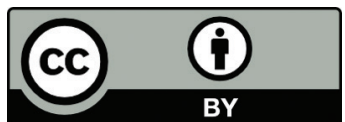

This work is licensed under a Creative Commons Attribution 